\title{
Mapping insecticide resistance in Anopheles gambiae (s.l.) from Côte d'Ivoire
}

Soromane Camara ${ }^{1,2}$, Alphonsine A. Koffi ${ }^{*}$, Ludovic P. Ahoua Alou' ${ }^{1}$, Kouakou Koffi ${ }^{2}$, Jean-Paul K. Kabran ${ }^{1}$, Aboubacar Koné ${ }^{1}$, Mathieu F. Koffi ${ }^{1}$, Raphaël N'Guessan ${ }^{1,3}$ and Cédric Pennetier ${ }^{1,4^{*}}$

\begin{abstract}
Background: Insecticide resistance in malaria vectors is an increasing threat to vector control tools currently deployed in endemic countries. Resistance management must be an integral part of National Malaria Control Programmes' (NMCPs) next strategic plans to alleviate the risk of control failure. This obviously will require a clear database on insecticide resistance to support the development of such a plan. The present work gathers original data on insecticide resistance between 2009 and 2015 across Côte d'Ivoire in West Africa.
\end{abstract}

Methods: Two approaches were adopted to build or update the resistance data in the country. Resistance monitoring was conducted between 2013 and 2015 in 35 sentinel sites across the country using the WHO standard procedure of susceptibility test on adult mosquitoes. Four insecticide families (pyrethroids, organochlorides, carbamates and organophosphates) were tested. In addition to this survey, we also reviewed the literature to assemble existing data on resistance between 2009 and 2015.

Results: High resistance levels to pyrethroids, organochlorides and carbamates were widespread in all study sites whereas some Anopheles populations remained susceptible to organophosphates. Three resistance mechanisms were identified, involving high allelic frequencies of $k d r$ L1014F mutation (range $=0.46-1$ ), relatively low frequencies of ace- $r^{R}$ (below 0.5 ) and elevated activity of insecticide detoxifying enzymes, mainly mixed function oxidases (MFO), esterase and glutathione S-transferase (GST) in almost all study sites.

Conclusion: This detailed map of resistance highlights the urgent need to develop new vector control tools to complement current long-lasting insecticidal nets (LLINs) although it is yet unclear whether these resistance mechanisms will impact malaria transmission control. Researchers, industry, WHO and stakeholders must urgently join forces to develop alternative tools. By then, NMCPs must strive to develop effective tactics or plans to manage resistance keeping in mind country-specific context and feasibility.

Keywords: Malaria vectors, Resistance, Insecticides, Côte d'Ivoire

\section{Background}

Malaria remains the deadliest tropical infectious disease, causing an estimated 429,000 deaths worldwide in 2015 of which $90 \%$ occurred in sub-Saharan Africa [1]. The disease is caused by Plasmodium parasites that are transmitted to humans in Africa mainly by Anopheles gambiae, An. coluzzii, An. arabiensis and An. funestus [2]. The first three species are members of the An. gambiae complex [3]. The dominant mosquito species responsible

\footnotetext{
*Correspondence: koffi_alphonsine@yahoo.fr; cedric.pennetier@ird.fr ${ }^{1}$ Institut Pierre Richet/Institut National de Santé Publique (IPR/INSP), BP 1500 Bouake, Côte d'Ivoire

Full list of author information is available at the end of the article
}

for the malaria transmission in Côte d'Ivoire are mainly An. gambiae and An. coluzzii that are widespread over the country $[4,5]$. They are well adapted to all types of breeding sites (permanent breeding sites or temporary rain pools such as puddles, shallow wells, footprints, or in rice and vegetable fields) in both rural and urban areas.

Malaria vector control in sub-Saharan Africa relies predominantly on long-lasting insecticidal nets (LLINs) and indoor residual spraying (IRS). The World Health Organization (WHO) recommends different LLINs and IRSs formulations that meet safety and efficacy criteria [6]. The fifteen products recommended for IRS belong to four chemical classes (carbamates, organochlorides, 
organophosphates and pyrethroids) but only pyrethroid insecticides are currently used in the manufacture of LLINs. However, the widespread use of insecticides for agricultural, domestic or public health purpose has led to the rapid development of insecticide resistance, which constitutes a serious threat to the efficacy of the current arsenal. Resistance to these compounds has been largely described in human disease vectors, especially in the African malaria vectors [7-9].

In 2012, WHO launched a Global Plan for Insecticide Resistance Management in malaria vectors (GPIRM). This plan was widely disseminated to the member states and the African Network on Vector Resistance (ANVR) and served as a springboard to its rollout and implementation in the African region [10]. Subsequently, a roadmap for the implementation of GPIRM was developed by ANVR. Following this roadmap, endemic countries were encouraged to build a strong resistance database and to elaborate a malaria vector control plan for effective management of insecticide resistance in their specific ecological settings. In many countries, resistance data are sparse and not up to date, impeding the design of a solid resistance management plan. The development of a resistance management plan requires a close partnership and collaboration between NMCPs and qualified research institutions to map up resistance in a country.

The current paper presents the results of insecticide resistance monitoring from 2013 to 2015 under the initiative of NMCP. To provide readers with the most exhaustive database, a review of the literature was also carried out for the years 2009 to 2015 and relevant data added. The present document is structured into two main parts: (i) the insecticide resistance phenotypes observed in malaria vector populations sampled across the country, and (ii) the detection of underlying resistance mechanisms.

\section{Methods}

Study area

Côte d'Ivoire is a West African country of 322,462 square kilometres and 22 million inhabitants. It borders Burkina Faso and Mali in the North, Liberia and Guinea in the West, Ghana in the East and the Atlantic Ocean in the South (Fig. 1). The climate is equatorial in the south, tropical in the central region and semi-arid in the far north. Seasons are distinguishable by rainfall and temperature. The country is divided into four climatic zones and seasons characterized by a type of vegetation. Four seasons characterize the Southern region with an equatorial climate: a long rainy season from April to mid-July and a short rainy season from September to November, alternating with a short dry season from mid-July to September and a long dry season from December to March. The climate in the western part is subequatorial, (mountain climate) with similar seasons to the southern region. The south and west part of the country is characterized by dense forest (ombrophile and mesophile forest) whereas the centre has an equatorial climate and opens up to a transition between the south and north. Four seasons are observed: a long rainy season from March to June and a short rainy season from September to October. The long dry season starts in November through to February and a short dry season from July to August. The northern region belongs to the tropical climate (Sudanian climate) with two main seasons: a long rainy season from June to September and a long dry season with rare rainfall from October to May. Vegetation in the northern part of the country consists mainly of the savannah.

\section{Mosquito collections}

Anopheles larvae collection were done between June 2013 and December 2015 during the raining season in 35 localities (Fig. 1). To avoid any sampling bias, mosquito larvae were sampled in breeding sites at least one $\mathrm{km}$ apart and within a radius of $10 \mathrm{~km}$ around each locality. Specimens were then pooled per locality, brought back and reared to the adult stage in the insectary of the Institut Pierre Richet (Bouake, Côte d'Ivoire). Larvae were fed TetraMin ${ }^{\circ}$ fish food and adults with $10 \%$ honey solution.

\section{Insecticide susceptibility tests}

Bioassays were carried out using the standard WHO protocol [11]. Tests were performed with four pyrethroids $(0.75 \%$ permethrin, $0.05 \%$ deltamethrin, $0.05 \%$ alpha-cyperméthrin and $0.05 \%$ lambdacyhalothrin), one organochloride ( $4 \%$ DDT), two carbamates $(0.1 \%$ bendiocarb and $0.4 \%$ carbosulfan) and three organophosphates ( $1 \%$ fenitrothion, $1 \%$ pyrimiphos-methyl and $0.4 \%$ chlorpyriphos-methyl). Two to four-days-old unfed adult females of An. gambiae (s.l.) collected at the larval stage and reared until adults emerged were tested. The susceptible Kisumu strain was also tested. Four batches of 25 mosquitoes per insecticide were exposed to the treated papers for $60 \mathrm{~min}$ at $25 \pm 2{ }^{\circ} \mathrm{C}$ and $80 \%$ relative humidity. Negative controls consisted of batches of mosquitoes from each site exposed to untreated papers. After exposure, mosquitoes were transferred to the observation tube and provided with $10 \%$ honey solution and held for $24 \mathrm{~h}$ before scoring mortality. After the bioassays, unexposed mosquitoes (i.e. from the control tubes) were individually dry-frozen at $-80{ }^{\circ} \mathrm{C}$ for biochemical and molecular analysis.

\section{Species identification, target site mutations genotyping and biochemical assays}

Genomic DNA was extracted from individual mosquitoes using cetyl trimethyl ammonium bromide (CTAB) 


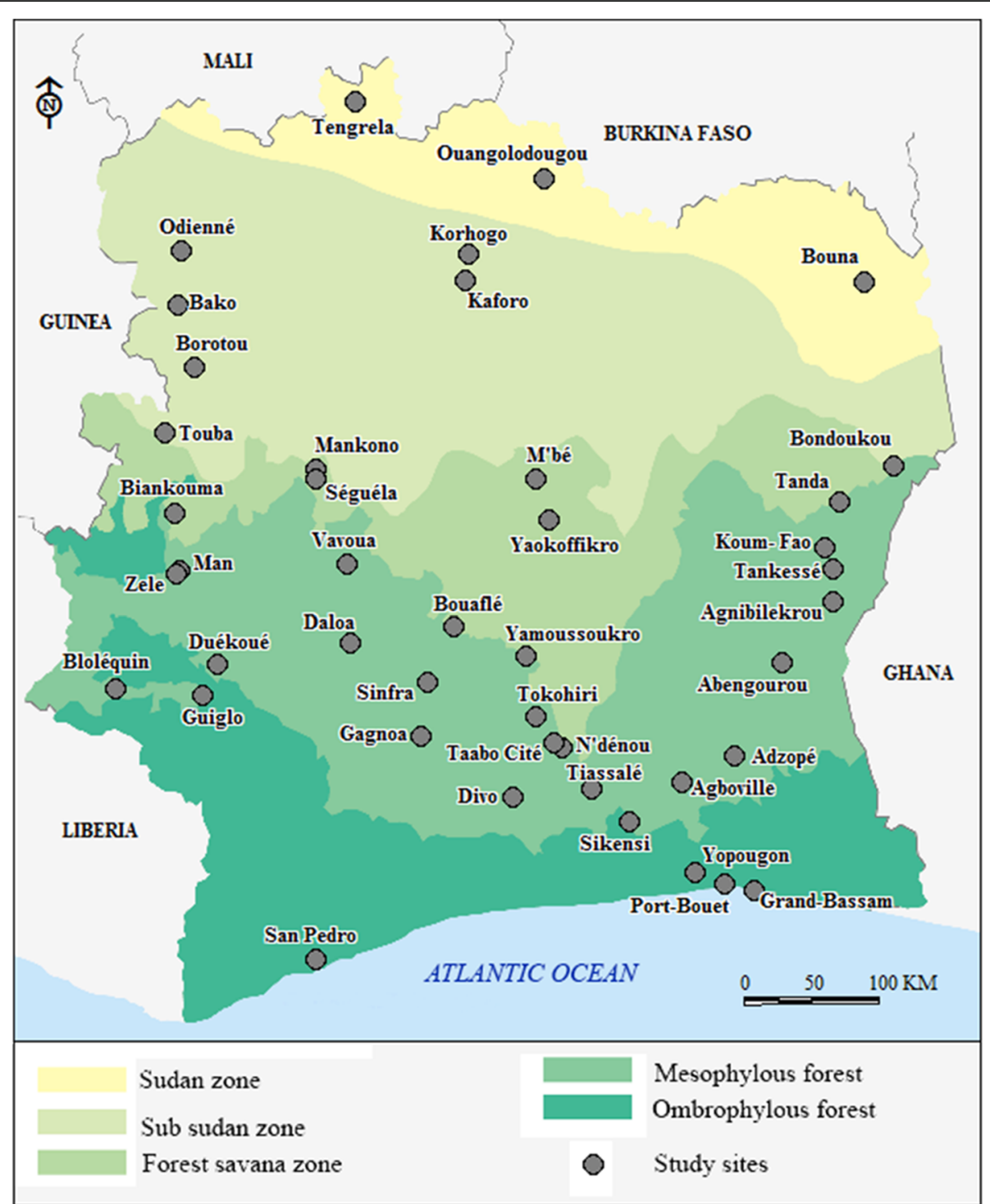

Fig. 1 Localization of the Anopheles spp. larval collection sites in different ecological zones of Côte d'Ivoire

2\% method described in Yahouedo et al. [12]. Species identification of the An. gambiae complex members were done as per Scott et al. [13] and Favia et al. [14]. The presence of L1014F and L1014S $k d r$ mutations were assessed by PCR using the method described by Martinez-Torres et al. [15] and Ranson et al. [16]. The PCR-RFLP diagnostic test was used to detect G119S ace $-1^{R}$ mutation as described by Weill et al. [17].

Biochemical assays were performed to quantify the mean activity of mixed function oxidases (MFO), and the mean activities of non-specific esterases (NSE) for alphaand beta-naphthyl acetate and glutathione S-transferases (GST) using female mosquitoes unexposed as described by WHO [18].

\section{Other data sources}

In addition to the 35 localities where bioassays were carried out, data from 8 localities spread over the country were obtained via PubMed, research centres and national universities, leading to a total of 43 localities investigated for insecticide resistance in malaria vectors. A literature search of published papers and reports from national institutions on insecticide resistance in the country using WHO standard assays was performed. We used Côte d'Ivoire, Anopheles, An. gambiae, insecticide resistance, $k d r$ and $A c e-1^{R}$ as keywords in database searches.

The literature search was done on PubMed and Google Scholar during December 2015. Data were also 
extracted from reports of national universities and research institutes. After careful reading, the following data were recorded: locality name, GPS coordinates (longitude and latitude) of locality and mosquito collection period. For each site, entomological data were extracted and added to the insecticide resistance database generated with WHO tube test results. These data were species of Anopheles, insecticide class/type/dosage, number of mosquitoes exposed per assay, mortality rates and susceptibility status. Regarding the resistance mechanisms, data extracted were the frequency of target site mutations, detoxifying enzyme quantities and/or activity rates together with the analysis protocols that had been used.

\section{Data analysis}

Insecticides susceptibility or resistance status was determined following WHO criteria. According to WHO recommendation made in 2013, 98-100 mosquitoes' mortality indicate susceptibility, 90-97\% suggests a suspected resistance that needs to be confirmed, $<90 \%$ mortality indicate resistance. Genotypic frequencies at $k d r$ L1014F and ace- $1^{R}$ G119S loci in An. gambiae (s.l.) wild populations were tested for goodness-of-fit to Hardy-Weinberg expectations using Fischer's exact tests generated with the Genepop 4.0 software [19]. Biochemical assay data (enzymatic activity per mg protein) were compared between a susceptible An. gambiae reference strain (Kisumu) and the wild vector populations from twenty-two sites by a Kruskal-Wallis non-parametric test.

\section{Results}

\section{Insecticide susceptibility across the country}

The mortality rate of the Kisumu reference strain to all insecticides was $100 \%$ indicating the good bio-availability of the insecticide active ingredients on the papers.

Insecticide susceptibility status of the wild population of An. gambiae (s.l.) was tested across Cote d'Ivoire with pyrethroid insecticides in 43 localities. Pyrethroid resistance was already widespread in all study sites (Table 1). Nevertheless, populations from two areas in the northern part (Kaforo and Korhogo) appeared to be fully susceptible to deltamethrin (98-100\% mortality). There were still some appreciable levels of mortality with this insecticide among populations from the east side (Adzope and Abengourou) (91-97\% mortality) and one place in the centre (Tokohiri) (92\%), although they fall within WHO range for suspicion of resistance. Similar suspicion of resistance to permethrin was noticed in those from Man, Ndenou, Taabo Cite and Yopougon (93-98\% mortality).

DDT resistance was widespread, with mortality ranging between $0-43 \%$ in $21 / 23$ areas tested (Table 1). There was resistance to the carbamates (carbosuflfan and bendiocarb) except in Duekoue in the west and Sans
Pedro in the south where resistance to bendiocarb was not clear-cut and therefore under suspicion.

Organophosphate insecticides (chlorpyrifos-methyl, pyrimifos-methyl and fenithrotion) induced far higher mortality than any other insecticide family. Indeed, populations from all areas except Tiassale showed full susceptibility $(99-100 \%$ mortality) to chlorpyrifosmethyl. With pyrimifos-methyl, nearly half of the areas tested (11/21) were fully susceptible and the over half resistant or suspected for resistance, with various levels of mortality scored in the bioassays (4$83 \%$ for confirmed resistance and $91-96 \%$ for the suspicion of resistance) (Table 2).

\section{Species and target site mutation distribution}

Species identification showed that Anopheles gambiae (s.l.) samples were composed of two species; Anopheles gambiae (s.s.) and Anopheles coluzzi. Anopheles gambiae was dominant in the sub-Sudanian area whereas $A n$. coluzzi was dominant in the forest area.

The L1014F and L1014S $k d r$ mutations were studied in 29/43 sites investigated. There was no L1014S $k d r$ mutation found in An. gambiae (s.s.) samples but the presence of the L1014F mutation was observed in all populations from the twenty-nine sites. Allelic frequencies varied from 0.4 to 1 . Most of the An. gambiae (s.s.) populations $(18 / 29)$ displayed high frequencies $(k d r$ frequency $\geq 0.8$ ) whereas, moderate allelic frequencies between $0.5-0.8$ were detected in eight populations. The allelic frequencies were below 0.5 in only 3 out of 29 populations tested (Table 3). The ace- $1^{R}$ G119S mutation was detected in 25 areas analyzed. Tiassale and Yaokoffikro populations had the highest allelic frequencies $\left(\right.$ ace- $1^{R}$ frequencies $\left.=0.50\right)$. The frequencies in the other areas ranged between $0-0.35$ (Table 3 ).

\section{Levels of enzyme activity}

The quantity or activity of three main detoxifying enzyme families was measured in 22 vector populations from Côte d'Ivoire. Elevated alpha- esterase was observed in 16 populations and beta-esterase in 12 sites, in comparison to susceptible mosquitoes. The highest esterase activity was recorded for An. gambiae (s.l.) from Yopougon, Port-Bouët, Korhogo and Yaokoffikro (Kruskal-Wallis H-test: $X^{2}=64.60, d f=21, P<0.001$ ) (Table 4). Oxidase activity was more elevated in nine populations than in Kisumu mosquitoes (Kruskal-Wallis H-test: $\left.\chi^{2}=67.74, d f=22, P<0.001\right)$. The highest levels of oxidase activity were observed in Kaforo in the North and Man in the West, with 4-fold higher activity than in Kisumu (Table 4). Elevated GST activity was observed in $90 \%(18 / 20)$ of the populations relative to activity in the Kisumu mosquitoes (Kruskal-Wallis H-test: $X^{2}=61.78$, 
Table 1 Pyrethroid and organochlorine susceptibility of wild population of Anopheles gambiae (s.l.) in 43 sites in Côte d'Ivoire

\begin{tabular}{|c|c|c|c|c|c|c|c|c|c|c|c|c|c|c|c|c|}
\hline \multirow[t]{3}{*}{ Locality } & \multicolumn{12}{|c|}{ Pyrethroids } & \multirow{2}{*}{\multicolumn{3}{|c|}{$\begin{array}{l}\text { Organochlorine } \\
\text { DDT } 4 \%\end{array}$}} & \multirow[b]{3}{*}{ Ref } \\
\hline & \multicolumn{3}{|c|}{ Permethrin $0.75 \%$} & \multicolumn{3}{|c|}{ Deltamethrin $0.05 \%$} & \multicolumn{3}{|c|}{ Alphacypermethrin $0.05 \%$} & \multicolumn{3}{|c|}{ Lambdacyhalothrin $0.05 \%$} & & & & \\
\hline & $n$ & $\%$ Mort & $\overline{\text { Status }}$ & $\bar{n}$ & $\%$ Mort & $\overline{\text { Status }}$ & $\mathrm{n}$ & \% Mort & Status & $n$ & $\%$ Mort & Status & $n$ & $\%$ Mort & $\overline{\text { Status }}$ & \\
\hline Abengourou & 101 & 61.8 & $R$ & 101 & 97.0 & RS & 105 & 82.9 & $\mathrm{R}$ & - & - & - & 106 & 66.1 & $\mathrm{R}$ & \\
\hline Adzopé & 100 & 42.0 & R & 96 & 90.6 & RS & - & - & - & 102 & 67.7 & $\mathrm{R}$ & - & - & - & [54] \\
\hline Agboville & - & - & - & 116 & 62.9 & $\mathrm{R}$ & - & - & - & - & - & - & - & - & - & [55] \\
\hline Agnibilekro & 99 & 23.2 & $\mathrm{R}$ & 103 & 74.3 & $\mathrm{R}$ & 103 & 20.4 & $\mathrm{R}$ & - & - & - & 101 & 0.3 & $\mathrm{R}$ & \\
\hline Bako & - & - & - & 108 & 0.9 & $\mathrm{R}$ & - & - & - & - & - & - & - & - & - & \\
\hline Biankouma & 100 & 0 & R & 97 & 28.9 & $\mathrm{R}$ & 101 & 9.9 & $\mathrm{R}$ & - & - & - & - & - & - & \\
\hline Bloléquin & 20 & 10.0 & R & 100 & 6.0 & $\mathrm{R}$ & - & - & - & - & - & - & - & - & - & \\
\hline Bondoukou & 105 & 17.1 & $\mathrm{R}$ & 104 & 50.9 & $\mathrm{R}$ & 104 & 9.6 & $\mathrm{R}$ & 101 & 37.6 & $\mathrm{R}$ & 98 & 8 & $\mathrm{R}$ & \\
\hline Borotou & 70 & 5.7 & R & 103 & 16.5 & $\mathrm{R}$ & 101 & 9.9 & $\mathrm{R}$ & - & - & - & - & - & - & \\
\hline Bouaflé & 99 & 13.1 & R & 70 & 54.3 & $\mathrm{R}$ & - & - & - & 96 & 9.4 & $\mathrm{R}$ & 106 & 0.9 & $\mathrm{R}$ & \\
\hline Bouna & 83 & 30.9 & R & - & - & - & - & - & - & - & - & - & - & - & - & \\
\hline Daloa & 105 & 18.1 & R & 102 & 43.1 & $\mathrm{R}$ & 98 & 24.5 & $\mathrm{R}$ & 99 & 7.1 & $\mathrm{R}$ & - & - & - & \\
\hline Divo & - & - & - & 99 & 64.6 & R & - & - & - & - & - & - & - & - & - & [55] \\
\hline Duékoué & 103 & 2.9 & R & 105 & 12.4 & $\mathrm{R}$ & - & - & - & 101 & 4.9 & $\mathrm{R}$ & - & - & - & \\
\hline Gagnoa & 103 & 6.8 & $\mathrm{R}$ & 98 & 33.7 & $\mathrm{R}$ & 73 & 2.7 & $\mathrm{R}$ & - & - & - & - & - & - & \\
\hline Grand-Bassam & 202 & 2.5 & R & 178 & 37.1 & $\mathrm{R}$ & 202 & 11.4 & $\mathrm{R}$ & 108 & 3.7 & $\mathrm{R}$ & 103 & 0.9 & $\mathrm{R}$ & \\
\hline Guiglo & 100 & 1.0 & $\mathrm{R}$ & 102 & 5.9 & $\mathrm{R}$ & 68 & 7.3 & $\mathrm{R}$ & - & - & - & - & - & - & \\
\hline Kaforo & - & - & - & 51 & 100 & S & - & - & - & - & - & - & - & - & - & \\
\hline Korhogo & 97 & 31.1 & R & 101 & 98.1 & $S$ & 100 & 70.0 & $\mathrm{R}$ & - & - & - & 105 & 6.5 & $\mathrm{R}$ & \\
\hline Koum- Fao & 102 & 40.2 & $\mathrm{R}$ & - & - & - & - & - & - & - & - & - & - & - & - & \\
\hline Man & 94 & 93.6 & RS & 88 & 73.9 & $\mathrm{R}$ & 99 & 73.8 & $\mathrm{R}$ & 104 & 10.6 & $\mathrm{R}$ & 101 & 40.6 & $\mathrm{R}$ & \\
\hline Mankono & - & - & - & 73 & 39.7 & $\mathrm{R}$ & - & - & - & - & - & - & - & - & - & \\
\hline M'bé & 201 & 51.1 & R & 274 & 75.8 & $\mathrm{R}$ & 240 & 67.9 & R & - & - & - & 193 & 3.1 & $\mathrm{R}$ & \\
\hline N'dénou & 103 & 93.0 & RS & 103 & 85.0 & $\mathrm{R}$ & - & - & - & - & - & - & 108 & 5.5 & $\mathrm{R}$ & [56] \\
\hline Odiénné & 98 & 5.1 & R & 106 & 8.5 & $\mathrm{R}$ & 105 & 5.7 & $\mathrm{R}$ & - & - & - & - & - & - & \\
\hline Ouangolo & 104 & 53.4 & R & 107 & 59.5 & $\mathrm{R}$ & 99 & 42.4 & $\mathrm{R}$ & 102 & 68.3 & $\mathrm{R}$ & 98 & 2.5 & - & \\
\hline Port-Bouet & 98 & 50.0 & R & 103 & 54.4 & $\mathrm{R}$ & 97 & 75.3 & $\mathrm{R}$ & 101 & 16.8 & $\mathrm{R}$ & 102 & 35.3 & $\mathrm{R}$ & \\
\hline San pedro & 106 & 73.0 & $R$ & 125 & 78.7 & $\mathrm{R}$ & 106 & 7.5 & $\mathrm{R}$ & 106 & 11.6 & $\mathrm{R}$ & 75 & 58.5 & $\mathrm{R}$ & \\
\hline Séguela & 102 & 5.9 & R & 98 & 29.6 & $\mathrm{R}$ & 99 & 21.2 & $\mathrm{R}$ & - & - & - & - & - & - & \\
\hline Sikensi & - & - & - & 81 & 51.9 & $R$ & - & - & - & - & - & - & - & - & - & [55] \\
\hline Sinfra & 104 & 0 & R & 101 & 7.9 & $\mathrm{R}$ & 99 & 2.0 & $\mathrm{R}$ & - & - & - & - & - & - & \\
\hline Taabo cité & 99 & 96.9 & RS & 107 & 89.7 & R & - & - & - & - & - & - & 111 & 17.1 & $\mathrm{R}$ & [56] \\
\hline Tanda & 86 & 66.3 & R & 89 & 69.6 & $\mathrm{R}$ & 79 & 69.6 & $\mathrm{R}$ & 108 & 30.6 & $\mathrm{R}$ & 80 & 37.6 & $\mathrm{R}$ & \\
\hline Tankéssé & 108 & 9.2 & R & 102 & 35.3 & R & 104 & 8.7 & $\mathrm{R}$ & 101 & 10.1 & $\mathrm{R}$ & 106 & 1.3 & $\mathrm{R}$ & \\
\hline Tengrela & 104 & 21.8 & R & 104 & 41.3 & $\mathrm{R}$ & 104 & 8.7 & $\mathrm{R}$ & 104 & 15.4 & $\mathrm{R}$ & 104 & 15.4 & $\mathrm{R}$ & \\
\hline Tiassalé & 204 & 24.0 & R & 282 & 31.9 & $\mathrm{R}$ & - & - & - & - & - & - & 306 & 8.2 & $\mathrm{R}$ & [24] \\
\hline Tokohiri & 103 & 54.4 & R & 107 & 91.6 & RS & - & - & - & - & - & - & 105 & 0 & $\mathrm{R}$ & [56] \\
\hline Touba & 101 & 1.9 & $\mathrm{R}$ & 106 & 62.3 & $\mathrm{R}$ & 100 & 28.0 & $\mathrm{R}$ & - & - & - & - & - & - & \\
\hline Vavoua & 108 & 11.1 & R & 99 & 7.1 & $\mathrm{R}$ & 104 & 17.3 & - & - & - & - & - & - & - & \\
\hline Yamoussoukro & 125 & 73.7 & $R$ & 102 & 23.5 & $\mathrm{R}$ & 100 & 50.0 & $\mathrm{R}$ & 100 & 16.8 & $\mathrm{R}$ & 101 & 3.0 & $\mathrm{R}$ & \\
\hline Yaokoffikro & 106 & 68.9 & $\mathrm{R}$ & 101 & 11.9 & $\mathrm{R}$ & 105 & 5.7 & $\mathrm{R}$ & 97 & 68.0 & $\mathrm{R}$ & 99 & 1.0 & $\mathrm{R}$ & \\
\hline
\end{tabular}


Table 1 Pyrethroid and organochlorine susceptibility of wild population of Anopheles gambiae (s.l.) in 43 sites in Côte d'Ivoire (Continued)

\begin{tabular}{|c|c|c|c|c|c|c|c|c|c|c|c|c|c|c|c|c|}
\hline \multirow[t]{3}{*}{ Locality } & \multicolumn{12}{|c|}{ Pyrethroids } & \multirow{2}{*}{\multicolumn{3}{|c|}{$\begin{array}{l}\text { Organochlorine } \\
\text { DDT } 4 \%\end{array}$}} & \multirow[b]{3}{*}{ Ref } \\
\hline & \multicolumn{3}{|c|}{ Permethrin $0.75 \%$} & \multicolumn{3}{|c|}{ Deltamethrin $0.05 \%$} & \multicolumn{3}{|c|}{ Alphacypermethrin 0.05\% } & \multicolumn{3}{|c|}{ Lambdacyhalothrin $0.05 \%$} & & & & \\
\hline & $n$ & $\%$ Mort & Status & $n$ & $\%$ Mort & Status & $n$ & $\%$ Mort & Status & $n$ & $\%$ Mort & Status & $n$ & $\%$ Mort & Status & \\
\hline Yopougon & 98 & 92.2 & RS & 104 & 89.4 & $\mathrm{R}$ & 99 & 100 & S & - & - & - & 102 & 29.4 & $\mathrm{R}$ & \\
\hline Zele & 77 & 74.2 & $\mathrm{R}$ & - & 69.2 & $\mathrm{R}$ & 104 & 82.7 & $\mathrm{R}$ & - & - & - & 93 & 43.4 & $\mathrm{R}$ & \\
\hline
\end{tabular}

Abbreviations: $n$, number of tested mosquitoes; -, no value; \% Mort, mortality rate $24 \mathrm{~h}$ post-exposure; $S$, susceptibility; $R S$, suspected resistance; $R$, resistance; Ref, reference

$d f=20, P<0.001)$. The highest GST activity (> 4-fold) was recorded for An. gambiae (s.l.) from Yopougon, Korhogo, Yamoussoukro and Port-Bouët (Table 4).

\section{Discussion}

A better management of insecticide resistance in malaria vectors relies on detailed and frequent resistance monitoring. Other vector bionomic data are also essential to build a relevant strategic plan. Local capacity with technical skills and financial support need to be strengthened to create the best environment to achieve such monitoring. In Côte d'Ivoire, the NMCP is working in close collaboration with universities and research institutions to build on the best evidence-based strategic plan to fight malaria. As a contribution to this approach, we updated the insecticide resistance status among malaria vectors in Côte d'Ivoire, relying on recent data package generated between 2009 and 2015. This study focused on $A n$. gambiae (s.l.), the major malaria vector in the country despite the presence of secondary vectors such as $A n$. funestus and $A n$. niili are also involved in malaria transmission. Overall, resistance to pyrethroids, organochlorides and carbamates is general in malaria vector populations of Côte d'Ivoire. Resistance to organophosphate insecticides was also widespread, but some malarial mosquito populations were still susceptible whereas some displayed moderate levels of resistance.

National research institutions [20] recently (2012) showed susceptibility to pyrethroids and organochlorides in the West and V-Baoulé in the central country. Moreover, all vector populations tested with fenitrothion and chlorpyrifos-methyl (organophosphates) were susceptible before 2009 [20]. The widespread and strong resistance both to organochlorides and pyrethroids as well as the moderate level of resistance to organophosphates in the present study illustrates the recent rapid evolution and spread of insecticide resistance to almost all public health insecticides. The distribution of resistance was patchy, and its intensity varies from one malaria vector population to another, highlighting the local selection of such phenotypes [21] as already illustrated in Culex pipiens species [22].

This rapid evolution relies on the selective pressure that has multiple origins. It was shown that agricultural use of pesticides and public health and domestic use of insecticide contribute to the selection and spread of resistance mechanisms in malaria vector populations in Côte d'Ivoire. The cause-consequence link is very difficult to establish; nevertheless, several papers suggested a link between the emergence and spread of the $k d r$ and ace- $1^{R}$ mutations in An. gambiae (s.s.) populations of Côte d'Ivoire and agricultural use of pyrethroids, carbamates and organophosphates insecticides to protect cotton, cocoa, coffee and rice crops [5, 23, 24]. In urban areas, another selection pressure source suggested is the pesticides used for vegetable growing [25]. Some studies have also shown that mosquito larvae exposed to sublethal doses of pollutants, herbicides or pesticides display an insecticide resistance through increased activities of insecticide-detoxifying enzymes [26, 27].

The highest frequencies of the $k d r$ mutation have been observed in the north which is a cotton growing area, in the east, in Abidjan, in San Pedro, Tiassalé, Daloa and in the Bouake area. The overall allele frequency of ace- $1^{R}$ was higher in Tiassalé and Yaokoffikro, both ricegrowing areas. These mutations have also been detected with high frequencies in An. gambiae (s.l.) in many regions of West Africa [28, 29] with ecological similarities in Burkina Faso and Benin (cotton, rice and urban/suburban vegetable growing areas) [30, 31].

Currently, the increasing use of insecticides for malaria vector control plays an important role in the insecticide selection pressure. According to Mathias et al. [32], ITN coverage for populations has been associated with a development of strong insecticide selection pressure by pyrethroid and increase of $k d r$ allele frequency. A reduction in the susceptibility of An. gambiae (s.l.) populations subjected to ITNs was also observed in Uganda [33]. Besides that, increase in $k d r$ frequencies was evidenced in $A n$. gambiae (s.l.) after the distribution of LLINs in Kenya [34], Niger [35], Senegal [36] and Benin [37]. In Côte d'Ivoire, more than 10,000,000 LLINs were distributed in 2014. This might have contributed to the selection pressure of insecticide resistance.

This study has also shown the involvement of detoxification enzymes in insecticide resistance in Côte d'Ivoire. The underlying metabolic mechanisms are currently under the spotlight, and a growing number of studies 
Table 2 Organophosphate and carbamate susceptibility of wild population of Anopheles gambiae (s.l.) in Côte d'Ivoire

\begin{tabular}{|c|c|c|c|c|c|c|c|c|c|c|c|c|c|c|c|c|}
\hline \multirow[t]{3}{*}{ Locality } & \multicolumn{6}{|c|}{ Carbamate } & \multicolumn{10}{|c|}{ Organophosphates } \\
\hline & \multicolumn{3}{|c|}{ Bendiocarb $0.1 \%$} & \multicolumn{3}{|c|}{ Carbosulfan $0.4 \%$} & \multicolumn{3}{|c|}{ Fenitrothion $1 \%$} & \multicolumn{3}{|c|}{ Pyrimifos-metyl $1 \%$} & \multicolumn{3}{|c|}{ Chlorpyrifos-methyl $0.4 \%$} & \multirow[b]{2}{*}{ Ref } \\
\hline & $n$ & $\%$ Mort & Status & $n$ & $\%$ Mort & Status & $n$ & $\%$ Mort & $\overline{\text { Status }}$ & $n$ & $\%$ Mort & Status & $n$ & $\%$ Mort & Status & \\
\hline Abengourou & - & - & - & 101 & 14.3 & $\mathrm{R}$ & - & - & - & 100 & 100 & $S$ & - & - & - & \\
\hline Agboville & 116 & 69.0 & $\mathrm{R}$ & - & - & - & 103 & 62.1 & $\mathrm{R}$ & 94 & 16.0 & $\mathrm{R}$ & - & - & - & {$[55]$} \\
\hline Agnibilekro & 101 & 67.3 & $\mathrm{R}$ & - & - & - & - & - & - & - & - & & 99 & 100 & S & \\
\hline Biankouma & 103 & 57.3 & $\mathrm{R}$ & - & - & - & 100 & 82.0 & $\mathrm{R}$ & 98 & 100 & S & - & - & - & \\
\hline Bondoukou & 106 & 89.6 & $\mathrm{R}$ & - & - & - & - & - & - & - & - & - & 104 & 100 & S & \\
\hline Bouaflé & 99 & 48.5 & $\mathrm{R}$ & - & - & - & 106 & 77.4 & $\mathrm{R}$ & 101 & 72.3 & $\mathrm{R}$ & - & - & - & \\
\hline Daloa & 93 & 67.7 & $\mathrm{R}$ & - & - & - & 103 & 94.2 & RS & 91 & 91.2 & RS & - & - & - & \\
\hline Divo & 199 & 77.9 & $\mathrm{R}$ & - & - & - & 196 & 98.0 & S & 58 & 43.8 & $\mathrm{R}$ & - & - & - & [55] \\
\hline Duékoué & 103 & 91.3 & RS & - & - & - & 103 & 99.0 & s & 98 & 100 & S & - & - & - & \\
\hline Gagnoa & - & - & - & - & - & - & 103 & 98.1 & S & - & - & - & - & - & - & \\
\hline Grand-Bassam & 124 & 52.4 & $\mathrm{R}$ & - & - & - & 102 & 83.0 & $\mathrm{R}$ & 108 & 3.7 & $\mathrm{R}$ & 103 & 99.0 & S & \\
\hline Guiglo & 107 & 85.0 & $\mathrm{R}$ & - & - & - & 98 & 100 & S & 100 & 100 & S & - & - & - & \\
\hline Kaforo & - & - & - & - & - & - & - & - & - & - & - & - & - & - & - & \\
\hline Korhogo & - & - & - & 97 & 14.8 & $\mathrm{R}$ & - & - & - & 99 & 82.7 & $\mathrm{R}$ & - & - & - & \\
\hline Man & - & - & - & 88 & 52.0 & $\mathrm{R}$ & - & - & - & 101 & 99.0 & S & - & - & - & \\
\hline Mankono & - & - & - & - & - & - & - & - & - & - & - & - & - & - & - & \\
\hline M'bé & 99 & 65.7 & $\mathrm{R}$ & 200 & 6.5 & $\mathrm{R}$ & 102 & 99.0 & S & 102 & 100 & S & 100 & 100 & S & \\
\hline Odiénné & 99 & 32.3 & $\mathrm{R}$ & - & - & - & 82 & 67.3 & $\mathrm{R}$ & - & - & - & - & - & - & \\
\hline Ouangolodougou & 107 & 59.8 & $\mathrm{R}$ & - & - & $\mathrm{R}$ & - & - & - & - & - & - & 104 & 100 & S & \\
\hline Port-Bouet & 102 & 9.8 & $\mathrm{R}$ & - & - & R & 99 & 96.0 & RS & 101 & 70.4 & $\mathrm{R}$ & - & - & - & \\
\hline San pedro & 105 & 92.4 & RS & 97 & 35.9 & R & - & - & - & - & - & - & 79 & 100 & S & \\
\hline Séguela & 97 & 23.7 & $\mathrm{R}$ & - & - & - & 97 & 68.0 & $\mathrm{R}$ & 100 & 100 & S & - & - & - & \\
\hline Sikensi & 108 & 56.5 & $\mathrm{R}$ & - & - & - & 111 & 82.2 & $\mathrm{R}$ & - & - & - & - & - & - & [55] \\
\hline Sinfra & 99 & 68.7 & $\mathrm{R}$ & - & - & - & 106 & 96.2 & RS & 100 & 100 & S & - & - & - & \\
\hline Tanda & 106 & 83.0 & $\mathrm{R}$ & - & - & - & - & - & - & - & - & - & 101 & 100 & S & \\
\hline Tankéssé & 105 & 80.0 & $\mathrm{R}$ & - & - & - & 76 & 93.4 & RS & - & - & - & 76 & 100 & S & \\
\hline Tengrela & 103 & 72.8 & $\mathrm{R}$ & - & - & - & 101 & 93.1 & RS & - & - & - & 99 & 100 & S & \\
\hline Tiassalé & 209 & 12.4 & $\mathrm{R}$ & 217 & 2.8 & R & 296 & 74.0 & $\mathrm{R}$ & 100 & 68.0 & $\mathrm{R}$ & 192 & 82.8 & R & [24] \\
\hline Touba & 100 & 51.0 & $\mathrm{R}$ & - & - & - & 102 & 83.3 & $\mathrm{R}$ & 98 & 100 & S & - & - & - & \\
\hline Vavoua & 101 & 68.3 & $\mathrm{R}$ & - & - & - & 104 & 96.2 & RS & 96 & 100 & S & - & - & - & \\
\hline Yamoussoukro & 97 & 52.6 & $\mathrm{R}$ & 104 & 42.7 & $\mathrm{R}$ & 100 & 91.0 & RS & 100 & 96.3 & RS & - & - & - & \\
\hline Yaokoffikro & 100 & 42.0 & $\mathrm{R}$ & 79 & 13.9 & $\mathrm{R}$ & 83 & 91.6 & RS & 102 & 100 & $S$ & 99 & 100 & S & \\
\hline Yopougon & - & - & - & 100 & 25.0 & $\mathrm{R}$ & - & - & - & 98 & 63.3 & $\mathrm{R}$ & - & - & - & \\
\hline
\end{tabular}

Abbreviations: $n$, number of tested mosquitoes; -, no value; $\%$ Mort, mortality rate $24 \mathrm{~h}$ post-exposure; $S$, susceptibility; $R S$, suspected resistance; $R$, resistance; Ref, reference

are investigating the cellular and molecular mechanisms that are driving such resistance phenotypes.

Despite the multiple resistance observed in the country, LLINs effectiveness has, until now, never been questioned [38]. However, some studies have shown a decrease of entomological efficiency in strong resistance zone [39]. Such LLINs insecticidal efficacy decrease has also been recently observed in the M'bé station, in central Côte d'Ivoire
(Ahoua Alou et al. submitted) where multiple resistance was confirmed a few years ago [40].

In this context, operational research urgencies are obvious. First of all, it is essential to decipher the interaction between insecticide resistance and operational efficacy or failure. In 2009, the WHO Global Malaria Programme with funding from the Bill \& Melinda Gates Foundation initiated a multi-country 
Table 3 Frequency of the kdr L1014F and ace- $1^{R}$ G119S mutations in An. gambiae (s.I.) from Côte d'Ivoire

\begin{tabular}{|c|c|c|c|c|c|c|c|c|c|c|c|}
\hline \multirow[t]{3}{*}{ Locality } & \multicolumn{4}{|c|}{ An. coluzzi } & \multicolumn{4}{|c|}{ An. gambiae Giles } & \multicolumn{3}{|c|}{ Frequency mutation in An gambiae (s.l.) population } \\
\hline & \multicolumn{2}{|c|}{$k d r$ L1014F } & \multicolumn{2}{|c|}{ ace- $1^{R}$ G119S } & \multicolumn{2}{|c|}{$k d r$ L1014F } & \multicolumn{2}{|c|}{ ace- $7^{R}$ G119S } & \multirow[b]{2}{*}{$n^{b}$} & \multirow[b]{2}{*}{$\mathrm{F}(k d r)$} & \multirow[b]{2}{*}{$\mathrm{F}\left(\right.$ ace $\left.-1^{R}\right)$} \\
\hline & $\overline{n^{a}}$ & $\mathrm{~F}(k d r)$ & $\overline{n^{a}}$ & $\mathrm{~F}\left(\right.$ ace $\left.-1^{R}\right)$ & $\overline{n^{a}}$ & $\mathrm{~F}(k d r)$ & $\overline{n^{a}}$ & $\mathrm{~F}\left(\right.$ ace- $\left.-1^{R}\right)$ & & & \\
\hline Abengourou & 29 & 0.517 & 29 & 0 & 29 & 0.666 & 3 & 0 & 32 & 0.531 & 0 \\
\hline Adzopé & - & - & - & - & - & - & - & - & 90 & 0.67 & - \\
\hline Agnibilekro & 5 & 1 & 5 & 0.200 & 39 & 1 & 39 & 0.269 & 44 & 1 & 0.261 \\
\hline Bingerville & 21 & 0.881 & 20 & 0.225 & 11 & 0.682 & 11 & 0.409 & 32 & 0.813 & 0.290 \\
\hline Bondoukou & 6 & 1 & 6 & 0.083 & 40 & 1 & 40 & 0.113 & 46 & 1 & 0.109 \\
\hline Bouna & 12 & 1 & 12 & 0.292 & 24 & 1 & 24 & 0.125 & 36 & 1 & 0.181 \\
\hline Daloa & 2 & 1 & 2 & 0.5 & 44 & 0.966 & 44 & 0.261 & 46 & 0.967 & 0.272 \\
\hline Divo & - & - & - & - & - & - & - & - & - & 0.807 & - \\
\hline Grand-Bassam & 36 & 0.986 & 41 & 0.329 & 4 & 1 & 5 & 0.200 & 40 & 0.988 & 0.315 \\
\hline Kaforo & 10 & 0.800 & 39 & 0.389 & 20 & 0.825 & 21 & 0.238 & 31 & 0.817 & 0.283 \\
\hline Korhogo & 9 & 0.722 & 8 & 0.062 & 23 & 0.761 & 23 & 0.283 & 32 & 0.750 & 0.226 \\
\hline Koum-Fao & 6 & 1 & 6 & 0.167 & 34 & 0.971 & 33 & 0.136 & 40 & 0.975 & 0.141 \\
\hline Man & - & - & - & - & - & - & - & - & 60 & 0.840 & 0.020 \\
\hline M'bé (Bouaké) & - & - & - & - & - & - & - & - & 226 & 0.800 & 0.020 \\
\hline N'Denou & - & - & - & - & - & - & - & - & 32 & 0.558 & - \\
\hline Ouangolodougou & 5 & 1 & 5 & 0.500 & 45 & 1 & 45 & 0.033 & 50 & 1 & 0.315 \\
\hline Port-bouet & 31 & 0.855 & 32 & 0.359 & 0 & - & 0 & - & 32 & 0.855 & 0.359 \\
\hline San-pedro & 46 & 1 & 46 & 0.174 & 0 & - & 0 & - & 46 & 1 & 0.174 \\
\hline Sassandra & 45 & 0.856 & 45 & 0.054 & 0 & - & 0 & - & 45 & 0.856 & 0.054 \\
\hline Taabo cité & - & - & - & - & - & - & - & - & 32 & 0.611 & - \\
\hline Tanda & 1 & 1 & 1 & 0.500 & 45 & 0.935 & 45 & 0.267 & 46 & 0.978 & 0.272 \\
\hline Tankéssé & 15 & 1 & 15 & 0.067 & 31 & 0.935 & 30 & 0.033 & 46 & 0.957 & 0.044 \\
\hline Tengrela & 22 & 0.955 & 22 & 0.136 & 24 & 1 & 24 & 0.208 & 46 & 0.978 & 0.174 \\
\hline Tiassalé & - & - & - & - & - & - & - & - & - & 0.830 & 0.500 \\
\hline Tokohiri & - & - & - & - & - & - & - & - & 32 & 0.519 & - \\
\hline Yamoussoukro & 26 & 0.479 & 26 & 0.135 & 5 & 0.500 & 5 & 0.100 & 31 & 0.484 & 0.125 \\
\hline Yaokoffikro & - & - & - & - & - & - & - & - & 111 & 0.940 & 0.500 \\
\hline Yopougon & 31 & 0.468 & 32 & 0.172 & - & - & - & - & 32 & 0.468 & 0.172 \\
\hline Zele & 7 & 0.5 & 7 & 0 & 25 & 0.500 & 25 & 0.260 & 32 & 0.500 & 0.203 \\
\hline
\end{tabular}

${ }^{\mathrm{a}}$ Number of mosquitoes tested by species

${ }^{\mathrm{b}}$ Total number tested

Abbreviations: $F(k d r)$, frequency of the kdr mutation; $F\left(a c e-1^{R}\right)$, frequency of the ace- $1^{R}$ mutation

study to ascertain the potential loss of epidemiological effectiveness of these core insecticidal interventions as a result of decreased susceptibility of malaria vectors to the insecticides used [41]. The longitudinal study was completed in four African countries (Benin, Cameroon, Kenya and Sudan) in 2016 and found no association between resistance and malaria prevalence where LLIN use was high [42].

Alternatives are currently available or under development. These alternatives could be classified into two main groups. The first comprises technologies that improve the efficacy of existing class of insecticide treated tools. In this group belong new LLINs treated with a synergist such as piperonyl butoxide and pyrethroids insecticide. Some of these have shown promising results against wild free-flying multi-resistant An. gambiae (s.s.) in experimental huts [34, 43-45]. This technology recommended by WHO aims to alleviate levels of resistance by removing the metabolic component of resistance due to MFOs and NSEs. The second group represents a group of new LLINs under development combining two insecticides with a different mode of action seems to be promising for controlling resistant mosquitoes [46]. This second category gathers complementary tools that could 
Table 4 Mean level of detoxifying enzyme activity in Anopheles gambiae (s.l.) in Côte d'Ivoire

\begin{tabular}{|c|c|c|c|c|}
\hline \multirow[t]{2}{*}{ Locality } & \multirow{2}{*}{$\begin{array}{l}\text { Alpha-esterase } \\
\mu \text { mol a-naphtol/min/mg } \\
\text { protein }(n)\end{array}$} & \multirow{2}{*}{$\begin{array}{l}\text { Beta-esterase } \\
\mu \mathrm{mol} \beta \text {-naphtol/min } / \mathrm{mg} \\
\text { protein }(n)\end{array}$} & \multirow{2}{*}{$\begin{array}{l}\text { Oxidases (MFO) } \\
\text { Nmol P450/mg } \\
\text { protein }(n)\end{array}$} & \multirow{2}{*}{$\begin{array}{l}\text { Glutathione S-transferase (GST } \\
\text { Nmol GST conj/min/mg } \\
\text { protein }(n)\end{array}$} \\
\hline & & & & \\
\hline Kisumu & $0.086(40)$ & $0.084(40)$ & $0.095(38)$ & $0.295(40)$ \\
\hline Abengourou & $0.036(32)$ & $0.043(32)$ & $0.251^{*}(31)$ & $0.501(25)$ \\
\hline Kaforo & $0.155^{*}(15)$ & 0.105 (15) & $0.330^{*}(15)$ & - \\
\hline Korhogo & $0.340^{*}(32)$ & $0.206^{*}(32)$ & $0.209^{*}(23)$ & $1.236^{*}(21)$ \\
\hline Man & $0.150 *(32)$ & $0.175^{*}(32)$ & $0.420^{*}(31)$ & $0.664^{*}(26)$ \\
\hline Port-bouet & $0.300 *(17)$ & $0.365^{*}(15)$ & $0.236^{*}(12)$ & $1.065^{*}(14)$ \\
\hline Yamoussoukro & $0.192^{*}(32)$ & $0.138^{*}(33)$ & $0.198^{*}(32)$ & $1.008^{*}(32)$ \\
\hline Yaokoffikro & $0.336^{*}(113)$ & - & 0.039 (113) & $0.154(108)$ \\
\hline Yopougon & $0.352^{*}(32)$ & $0.313^{*}(32)$ & $0.255^{*}(32)$ & $2.358^{*}(24)$ \\
\hline Zele & $0.107(32)$ & $0.089(32)$ & $0.163(33)$ & $0.638^{*}(28)$ \\
\hline Agnibilekro & $0.158^{*}(51)$ & - & $0.104(52)$ & $0.412^{*}(45)$ \\
\hline Bondoukou & $0.159 *(43)$ & $0.198^{*}(37)$ & $0.115(43)$ & $0.389 *(27)$ \\
\hline Bouna & - & $0.094(23)$ & 0.071 (33) & - \\
\hline Daloa & $0.052(43)$ & - & $0.077(42)$ & $0.639 *(42)$ \\
\hline Grand-Bassam & $0.133^{*}(50)$ & $0.109(43)$ & $0.164^{*}(50)$ & $0.471^{*}(44)$ \\
\hline Koum-Fao & $0.144^{*}(46)$ & $0.158^{*}(49)$ & $0.066(55)$ & $0.470^{*}(52)$ \\
\hline M'bé (Bouaké) & $0.155^{*}(40)$ & $0.125^{*}(40)$ & $0.198^{*}(36)$ & $0.378^{*}(40)$ \\
\hline Ouangolodougou & $0.127(48)$ & $0.105(33)$ & $0.079(43)$ & $0.362^{*}(40)$ \\
\hline San-pedro & $0.079(50)$ & $0.148^{*}(50)$ & $0.034(50)$ & $0.356^{*}(41)$ \\
\hline Sassandra & $0.136^{*}(35)$ & $0.089(30)$ & $0.066(35)$ & $0.805^{*}(35)$ \\
\hline Tanda & $0.204^{*}(45)$ & $0.230^{*}(48)$ & $0.094(49)$ & $0.380^{*}(41)$ \\
\hline Tankéssé & $0.183^{*}(53)$ & $0.137^{*}(53)$ & $0.133^{*}(53)$ & $0.515^{*}(53)$ \\
\hline Tengrela & $0.173^{*}(58)$ & $0.169^{*}(56)$ & $0.065(54)$ & $0.356^{*}(41)$ \\
\hline
\end{tabular}

Note: Kisumu result expresses enzyme activity in susceptible reference strain

Abbreviations: $\mathrm{n}$, number of mosquitoes tested; - , value not determined

${ }^{*} P<0.05$ : Enzyme level significantly higher compared to Kisumu strain

complement the massive distribution of LLINs (i.e. indoor residual spraying, larviciding, outdoor vector control set up and use of drugs with insecticidal properties such as Ivermectin) [47, 48]. Nevertheless despite the proof of principle of their potential efficacy, the randomized control trials showing the benefit to use them at community scale are scarce [49], and their ecological scope of the application does not seem to be global. Updated insecticide resistance data will also help to choose relevant areas to implement such randomized controlled trials $[50,51]$.

The NMCP of Côte d'Ivoire plans to integrate IRS and larviciding into malaria control policies. Given the high resistance to carbamates, pyrethroids and organochloride all over the country, our results indicate that only organophosphates (such as pyrimiphos-methyl or chlorpyriphosmethyl) could be advisable for IRS deployment.

Finally, physiological resistance mechanisms are closely interacting with behavioural adaptations in malaria vectors. There is an increasing number of evidence that malaria vector populations behave differently after wide insecticide pressure, due to a large LLINs distribution. These behavioural changes may affect the effectiveness of LLINs or IRS by reducing the possibility for a mosquito to contact insecticides in multiple ways as reviewed in Gatton et al. [52]. Behavioural adaptations and evolution of both mosquito and human populations are of crucial interest if the scientific community aims to understand better the residual transmission. As an example, a recent study highlighted the long-range effect (deterrent or attractive) of ITNs that may have significant consequences for personal and community protection against malaria transmission [53].

\section{Conclusion}

This study showed a wide distribution of pyrethroids, organochlorides and carbamate resistance in $A n$. gambiae (s.l.) in Côte d'Ivoire. Resistance to organophosphates was also widespread but some vector populations were still susceptible whereas others displayed a moderate level of resistance. These results could be used as a 
basis for the development of a strategic framework for strengthening malaria vector control implementation and insecticides resistance management. The rapid evolution since the last decade and patchy distribution of such resistance phenotypes indicate that monitoring insecticide resistance is essential and must be considered by authorities for the implementation of malaria control programs in Côte d'Ivoire.

\section{Abbreviations}

NMCP: National Malaria Control Programmes; WHO: World Health Organization; LLINs: Long-lasting insecticidal nets; IRS: Indoor residual spraying; L1014F $k d r$ : West knockdown resistance; ace- $1^{R}$ : Acetylcholinesterase-1 resistance; NSE: Non-specific esterase; MFO: Mixed-function oxidase; GST: Glutathione S-transferase; GPIRM: Global Plan for Insecticide Resistance Management; ANVR: African Network on Vector Resistance; IPR: Institut Pierre Richet; ace- P $^{P}$ G119S: G199S mutation in ace-1 $1^{R}$; DDT: Dichlorodiphenyltrichloroethane; R: Resistant; S: Susceptible

\section{Acknowledgements}

We wish to thank the technical staff at the Institut Pierre Richet, Bouaké, Côte d'lvoire for their valued support during the testing of mosquitoes, Finally we are very grateful to our colleagues from various disciplines from Côte d'Ivoire for their useful contribution towards the study.

\section{Funding}

The study was supported by World Health Organization (WHO) as a part of Global Plan for Insecticide Resistance Management in malaria vectors (GPIRM) and Vestergaard Frandsen WHO and Vestergaard approved the decision to publish. CS is supported by IRD fellowship.

\section{Availability of data and materials}

All data generated or analysed during this study are included in this published article.

\section{Authors' contributions \\ KAA and AAPL designed the study. AAPL, CS, KKJP, KA and KFM conducted the field and laboratory work. CS, AAPL and PC analysed and drafted the manuscript. KK, KAA, PC and NR supervised the study and revised the manuscript. All authors read and approved the final manuscript.}

\section{Ethics approval and consent to participate}

Not applicable.

\section{Consent for publication}

Not applicable.

\section{Competing interests}

The authors declare that they have no competing interests.

\section{Publisher's Note}

Springer Nature remains neutral with regard to jurisdictional claims in published maps and institutional affiliations.

\section{Author details}

${ }^{1}$ Institut Pierre Richet/Institut National de Santé Publique (IPR/INSP), BP 1500 Bouake, Côte d'Ivoire. ' $U$ niversité Félix Houphouët Boigny (UFHB), 22 BP 582 Abidjan 22, Côte d'Ivoire. ' ${ }^{3}$ London School of Hygiene and Tropical Medicine, London, UK. ${ }^{4}$ Institut de Recherche pour le Développement (IRD), Maladies Infectieuses et Vecteurs, Ecologie, Génétique, Evolution et Control (MIVEGEC), UMR 5290 CNRS-IRD-UM, Montpellier, France.
Received: 2 June 2017 Accepted: 21 November 2017

Published online: 08 January 2018

\section{References}

1. World Malaria Report 2016 - 9789241511711-eng.pdf. Available from:http:// apps.who.int/iris/bitstream/10665/252038/1/9789241511711-eng.pdf?ua=1. Accesses on 16 February 2017.

2. Sinka ME, Golding N, Massey NC, Wiebe A, Huang Z, Hay SI, et al. Modelling the relative abundance of the primary African vectors of malaria before and after the implementation of indoor, insecticide-based vector control. Malar J. 2016:15:142.

3. Coetzee M, Hunt RH, Wilkerson R, Della Torre A, Coulibaly MB, Besansky NJ. Anopheles coluzzii and Anopheles amharicus, new members of the Anopheles gambiae complex. Zootaxa. 2013;3619:246-74.

4. della Torre A, Tu Z, Petrarca V. On the distribution and genetic differentiation of Anopheles gambiae s.s. molecular forms. Insect Biochem Mol Biol. 2005;35:755-69.

5. Koffi AA, Alou LPA, J-PK K, N'Guessan R, Pennetier C. Re-visiting insecticide resistance status in Anopheles gambiae from Côte d'Ivoire: A nation-wide informative survey. Plos One. 2013;8:e82387.

6. WHOPES recommended insecticides for indoor residual spraying against malaria vectors - Insecticides IRS 2 March_2015.pdf. Available from: http://www.who.int/whopes/Insecticides_IRS_2_March_2015.pdf. Accessed on 28 February 2017.

7. Knox TB, Juma EO, Ochomo EO, Pates Jamet $H$, Ndungo L, Chege $P$, et al. An online tool for mapping insecticide resistance in major Anopheles vectors of human malaria parasites and review of resistance status for the Afrotropical region. Parasit Vectors. 2014;7:76.

8. Silva APB, Santos JMM, Martins AJ. Mutations in the voltage-gated sodium channel gene of anophelines and their association with resistance to pyrethroids - a review. Parasit Vectors. 2014;7:450.

9. Corbel V, N'Guessan R. Distribution, mechanisms, impact and management of insecticide resistance in malaria vectors: A pragmatic review. 2013. Available from: http://www.intechopen.com/books/anopheles-mosquitoesnew-insights-into-malaria-vectors/distribution-mechanisms-impact-andmanagement-of-insecticide-resistance-in-malaria-vectors-a-pragmat. Accessed on 25 February 2017.

10. WHO. Q \& A on the Global plan for insecticide resistance management in malaria vectors. 2012. Available from:http://www.who.int/malaria/media/ insecticide_resistance_management_qa/en/. Accessed on 28 February 2017.

11. WHO. Test procedures for insecticide resistance monitoring in malaria vector mosquitoes (2d edition) - 9789241511575-eng.pdf. 2013. Available from: http://apps.who.int/iris/bitstream/10665/250677/1/9789241511575eng.pdf. Accessed on 8 March 2017.

12. Yahouédo GA, Cornelie S, Djègbè I, Ahlonsou J, Aboubakar S, Soares C, et al. Dynamics of pyrethroid resistance in malaria vectors in southern Benin following a large scale implementation of vector control interventions. Parasit Vectors. 2016:9:385

13. Scott JA, Brogdon WG, Collins FH. Identification of single specimens of the Anopheles gambiae complex by the polymerase chain reaction. Am J Trop Med Hyg. 1993;49:520-9.

14. Favia G, Lanfrancotti A, Spanos L, Sidén-Kiamos I, Louis C. Molecular characterization of ribosomal DNA polymorphisms discriminating among chromosomal forms of Anopheles gambiae s.s. Insect Mol Biol. 2001;10:19-23.

15. Martinez-Torres D, Chandre F, Williamson MS, Darriet F, Bergé JB, Devonshire $\mathrm{AL}$, et al. Molecular characterization of pyrethroid knockdown resistance $(\mathrm{kdr})$ in the major malaria vector Anopheles gambiae s.s. Insect Mol Biol. 1998;7:179-84.

16. Ranson H, Jensen B, Vulule JM, Wang X, Hemingway J, Collins FH. Identification of a point mutation in the voltage-gated sodium channel gene of Kenyan Anopheles gambiae associated with resistance to DDT and pyrethroids. Insect Mol Biol. 2000;9:491-7.

17. Weill H, Hughes JM, Churg AM. Changing trends in US mesothelioma incidence. Occup Environ Med. 2004;61:438-41.

18. WHO. Techniques to detect insecticide resistance mechanisms. Field and laboratory manual. Available from: http://www.who.int/whopes/resources/ who_cds_cpc_mal_98.6/en/. Accessed on 23 February 2017.

19. Raymond M, Rousset FGENEPOP. (Version 1.2): Population genetics software for exact tests and ecumenicism. J Hered. 1995;86:248-9. 
20. Koffi AA, Ahoua AP, Adja AM, Konan L, San M, Koné M, et al. Profil entomologique du paludisme en Côte d'Ivoire 1956-2009. PNLP-ANVR/ OMS/Afro: In rapport d'activité; 2009.

21. Ayala D, Ullastres A, González J. Adaptation through chromosoma inversions in Anopheles. Front Genet. 2014;5:129.

22. Labbe $\mathrm{P}$, Lenormand $\mathrm{T}$, Raymond $\mathrm{M}$. On the worldwide spread of an insecticide resistance gene: a role for local selection: Resistance gene: history, drift or selection. J Evol Biol. 2005;18:1471-84.

23. Ahoua Alou LP, Koffi AA, Adja MA, Tia E, Kouassi PK, Koné M, et al. Distribution of ace-1R and resistance to carbamates and organophosphates in Anopheles gambiae s.s. populations from Côte d'Ivoire. Malar J. 2010;9:167.

24. Chouaibou MS, Chabi J, Bingham GV, Knox TB, N'Dri L, Kesse NB, et al. Increase in susceptibility to insecticides with aging of wild Anopheles gambiae mosquitoes from Côte d'Ivoire. BMC Infect Dis. 2012;12:214.

25. Luc DS, Benoit A, Laurette D, Michel M. Indirect evidence that agricultural pesticides select for insecticide resistance in the malaria vector Anopheles gambiae. J Vector Ecol. 2016;41:34-40.

26. Nkya TE, Akhouayri I, Kisinza W, David J-P. Impact of environment on mosquito response to pyrethroid insecticides: facts, evidences and prospects. Insect Biochem Mol Biol. 2013;43:407-16.

27. Poupardin R, Riaz MA, Jones CM, Chandor-Proust A, Reynaud S, David J-P. Do pollutants affect insecticide-driven gene selection in mosquitoes? Experimental evidence from transcriptomics. Aquat Toxicol Amst Neth. 2012;114-115:49-57.

28. Okorie PN, Ademowo GO, Irving H, Kelly-Hope LA, Wondji CS. Insecticide susceptibility of Anopheles coluzzii and Anopheles gambiae mosquitoes in Ibadan, South-West Nigeria. Med Vet Entomol. 2015;29:44-50.

29. Santolamazza F, Calzetta M, Etang J, Barrese E, Dia I, Caccone A, et al. Distribution of knock-down resistance mutations in Anopheles gambiae molecular forms in west and west-central Africa. Malar J. 2008;7:74.

30. Jones CM, Toé HK, Sanou A, Namountougou M, Hughes A, Diabaté A, et al. Additional selection for insecticide resistance in urban malaria vectors: DDT resistance in Anopheles arabiensis from Bobo-Dioulasso, Burkina Faso. PLoS One. 2012;7:e45995.

31. Djogbénou L, Pasteur N, Akogbéto M, Weill M, Chandre F. Insecticide resistance in the Anopheles gambiae complex in Benin: a nationwide survey. Med Vet Entomol. 2011;25:256-67.

32. Mathias DK, Ochomo E, Atieli F, Ombok M, Nabie Bayoh M, Olang G, et al. Spatial and temporal variation in the kdr allele L1014S in Anopheles gambiae s.s. and phenotypic variability in susceptibility to insecticides in western Kenya. Malar J. 2011;10:10.

33. John R, Ephraim T, Andrew A. Reduced susceptibility to pyrethroid insecticide treated nets by the malaria vector Anopheles gambiae s.l. in western Uganda. Malar J. 2008;7:92.

34. Stump AD, Atieli FK, Vulule JM, Besansky NJ. Dynamics of the pyrethroid knockdown resistance allele in western Kenyan populations of Anopheles gambiae in response to insecticide-treated bed net trials. Am J Trop Med Hyg. 2004;70:591-6.

35. Czeher C, Labbo R, Arzika I, Duchemin J-B. Evidence of increasing Leu-Phe knockdown resistance mutation in Anopheles gambiae from Niger following a nationwide long-lasting insecticide-treated nets implementation. Malar J. 2008;7:189.

36. Ndiath MO, Mazenot C, Sokhna C, Trape J-F. How the malaria vector Anopheles gambiae adapts to the use of insecticide-treated nets by African populations. PLoS One. 2014;9:e97700.

37. Aïzoun N, Aïkpon R, Akogbéto M. Evidence of increasing L1014F kdr mutation frequency in Anopheles gambiae s.l. pyrethroid resistant following a nationwide distribution of LLINs by the Beninese National Malaria Control Programme. Asian Pac J Trop Biomed. 2014;4:239-43.

38. Henry M-C, Assi S-B, Rogier C, Dossou-Yovo J, Chandre F, Guillet P, et al. Protective efficacy of lambda-cyhalothrin treated nets in Anopheles gambiae pyrethroid resistance areas of Côte d'Ivoire. Am J Trop Med Hyg. 2005;73:859-64.

39. N'Guessan R, Corbel V, Akogbéto M, Rowland M. Reduced efficacy of insecticide-treated nets and indoor residual spraying for malaria control in pyrethroid resistance area, Benin. Emerg Infect Dis. 2007;13:199-206.

40. Koffi AA, Alou LPA, Adja MA, Chandre F, Pennetier C. Insecticide resistance status of Anopheles gambiae s.s. population from M'Bé: a WHOPES-labelled experimental hut station, 10 years after the political crisis in Côte d'Ivoire. Malar J. 2013;12:1-8.
41. Kleinschmidt I, Mnzava AP, Kafy HT, Mbogo C, Bashir Al, Bigoga J, et al. Design of a study to determine the impact of insecticide resistance on malaria vector control: a multi-country investigation. Malar J. 2015 July 22;14:282.

42. Bradley J, Ogouyèmi-Hounto A, Cornélie S, Fassinou J, de Tove YSS, Adéothy AA, et al. Insecticide-treated nets provide protection against malaria to children in an area of insecticide resistance in Southern Benin. Malar J. 2017;16:225.

43. Tungu P, Magesa S, Maxwell C, Malima R, Masue D, Sudi W, et al. Evaluation of PermaNet 3.0 a deltamethrin-PBO combination net against Anopheles gambiae and pyrethroid-resistant Culex quinquefasciatus mosquitoes: an experimental hut trial in Tanzania. Malar J. 2010;9:21.

44. Corbel V, Chabi J, Dabiré RK, Etang J, Nwane P, Pigeon O, et al. Field efficacy of a new mosaic long-lasting mosquito net (PermaNet ${ }^{\circledR}$ 3.0) against pyrethroid-resistant malaria vectors: a multi centre study in Western and Central Africa. Malar J. 2010;9:113.

45. N'Guessan R, Asidi A, Boko P, Odjo A, Akogbeto M, Pigeon O, et al. An experimental hut evaluation of PermaNet ${ }^{\circledR}$ 3.0, a deltamethrin-piperonyl butoxide combination net, against pyrethroid-resistant Anopheles gambiae and Culex quinquefasciatus mosquitoes in southern Benin. Trans R Soc Trop Med Hyg. 2010;104:758-65.

46. N'Guessan R, Ngufor C, Kudom AA, Boko P, Odjo A, Malone D, et al. Mosquito nets treated with a mixture of chlorfenapyr and alphacypermethrin control pyrethroid resistant Anopheles gambiae and Culex quinquefasciatus mosquitoes in West Africa. PLoS One. 2014;9:e87710.

47. Djènontin $A$, Pennetier $C$, Zogo B, Soukou KB, Ole-Sangba M, Akogbéto M, et al. Field efficacy of Vectobac GR as a mosquito larvicide for the control of anopheline and culicine mosquitoes in natural habitats in Benin, West Africa. Plos One. 2014;9:e87934

48. Pooda HS, Rayaisse J-B, Hien DF de S, Lefèvre T, Yerbanga SR, Bengaly Z, et al. Administration of ivermectin to peridomestic cattle: a promising approach to target the residual transmission of human malaria. Malar J. 2015;14:496.

49. Killeen GF. Characterizing, controlling and eliminating residual malaria transmission. Malar J. 2014;13:330

50. Thomsen EK, Strode C, Hemmings K, Hughes AJ, Chanda E, Musapa M, et al. Underpinning sustainable vector control through informed insecticide resistance management. PLoS One. 2014;9(6):e99822.

51. Chanda E, Thomsen EK, Musapa M, Kamuliwo M, Brogdon WG, Norris DE, et al. An operational framework for insecticide resistance management planning. Emerg Infect Dis. 2016;22:773-9.

52. Gatton ML, Chitnis N, Churcher T, Donnelly MJ, Ghani AC, Godfray HCJ, et al. The importance of mosquito behavioural adaptations to malaria control in Africa. Evol Int J Org Evol. 2013;67:1218-30.

53. Moiroux N, Chandre F, Hougard J-M, Corbel V, Pennetier C. Remote effect of insecticide-treated nets and the personal protection against malaria mosquito bites. PLoS One. 2017;12(1):e017073254.

54. Ahoua Alou LP, Koffi AA, Adja MA, Assi SB, Kouassi PK, N'Guessan R. Status of pyrethroid resistance in Anopheles gambiae s.s. M form prior to the scaling up of long lasting insecticidal nets (LLINs) in Adzopé, Eastern Côte d'Ivoire. Parasit Vectors. 2012;5:289.

55. Edi CAV, Koudou BG, Bellai L, Adja AM, Chouaibou M, Bonfoh B, et al. Long-term trends in Anopheles gambiae insecticide resistance in Côte d'Ivoire. Parasit Vectors. 2014;7:500.

56. Bellai L. Evaluation de la résistance aux insecticides d'Anopheles gambiae à Taabo, Sud de la Côte d'Ivoire. DEA d'entomologie médicale, Université Félix Houphouët Boigny, Abidjan, Côte d'Ivoire; 2013, 50 p. 